\title{
FUNERAL AND ESTATE PLANNING FOR PEOPLE LIVING WITH HIV/AIDS

\author{
Some preliminary points
}

\author{
Elsabé Klinck \\ Director: Research, Compliance and Counselling, Foundation for Professional Development
}

The issue of funeral and estate planning should form part of HIV counselling, but this presupposes knowledge on the part of the counsellors/social workers/health care providers of basic legal principles underpinning the field of funeral and estate planning. Moreover, funeral and estate planning is often grounded in culture and religion, and perceptions of death, after-life, care of those left behind ('legacy', 'inheritance', etc.), burial and burial ceremonies, etc. This also relates to family relationships and family organisational structures and goes beyond the particular patient or client who visits a health establishment, voluntary counselling and testing (VCT) service or counselling service.

There may be a need for a patient/client brochure on this, possibly translated into all the official languages.

\section{ESTATE PLANNING AND APPLICABLE LEGISLATION}

People should know the difference between dying testate (with a will) and intestate (without a will) and the implications thereof. This also ties in with marital property and the recognition of the rights of people in polygamous unions.

The Wills Act of 1953 governs wills, and is important as it sets certain prerequisites for wills to be valid, including who may draft a will, who may witness it, and who may act as executor. It also deals with the effect of divorce and annulments on wills. The Intestate Succession Act of 1987 deals with persons who die without a will and basically provides 'rules' as to what will happen with a person's property in certain circumstances (e.g. whether person is survived by a spouse and/or parents and/or children, etc.). The Administration of Estates Act of 1965 provides for a number of issues that may also involve family members of a person planning his or her estate, such as reporting the death to the Master of the High Court. People should also be aware that certain financial institutions may undertake 'estate planning' and may draft wills of a general nature to their clients, of which the client may sometimes not even have a copy.
Two other factors complicate the above system, i.e. (i) inheritance in terms of traditional indigenous/cultural/ religious systems and (ii) marriage and life partnerships. The Matrimonial Property Act of 1984, most importantly the accrual system in terms of which after divorce or death 'of one or both of the spouses, the spouse whose estate shows no accrual or a smaller accrual than the estate of the other spouse, or his estate if he is deceased, acquires a claim against the other spouse or his estate for an amount equal to half of the difference between the accrual of the respective estates of the spouses'. People should be able to establish whether they are married in or out of community of property. People who have registered their 'marriages' in terms of the Recognition of Customary Marriages Act of 1998 have to take specific heed of the property consequences regulated by Section 7 of this Act. Women who are or were joined to a customary union as the second or further wife should be aware that the property consequences of their marriage will be or are governed by a contract set after application to a court of law.

Cohabitation is not governed by any South African law specifically as yet (the Law Commission is currently working on this), but people should be advised to 'formalise' their life/domestic partnerships by means of wills, the appointment of a partner and/or children as beneficiaries on their pension funds, life insurance policies, and setting agreements to deal with issues such as care of children after death, etc.

The Maintenance of Surviving Spouses Act of 1990 has as its objective to provide the surviving spouse in certain circumstances with a claim for maintenance against the estate of the deceased spouse, and from it some cases have been decided by our courts on who would qualify as a 'spouse'.

\section{PENSION FUNDS AND EMPLOYEE BENEFITS}

Certain pension or provident funds make provision for funeral and/or surviving spouses/partner benefits. Patients/clients should be encouraged to find out what the 
benefits and exclusions are in terms of HIV/AIDS and in terms of disability, funerals, etc. This could be done via trade union representatives, who often sit as trustees of pension/provident funds. The Promotion of Equality Act (mentioned below) may also be applicable in cases of alleged unfairness in terms of HIV-related benefits.

Specific laws, such as those applicable to the police services and the military, provide for (limited and restricted) funeral assistance.

\section{LONG-TERM INSURANCE AND FUNERAL POLICIES}

The following is an extract from the SAMA HIV Human Rights and Ethics Guidelines.

Medical practitioners are often approached to fill out forms relating to a patient's HIV status or whether he or she underwent an HIV test. The same ethical principle applies, i.e. patient information is confidential. Life insurance, burial policies, etc. often become problematic when a person who has been living with HIV dies or when the company suspects that the insured person may be HIV-positive. The primary contract is between the policyholder and the insurance company. The medical practitioner may only make medical details known if the insurance company can provide the medical practitioner with a copy of a document in which the patient has provided informed consent that his/her medical details may be released to the insurer. Failing that, the medical practitioner should only write 'confidential information' in the spaces provided and/or use the example above in relation to third-party requests as a response to the requesting company. If the insured person has died, the next of kin may consent to the disclosure of the medical information. Where the policyholder and the insured person are not the same, the insured person should provide informed consent before medical details are disclosed.

The medical practitioner should not take the responsibility for disclosing medical information where an insurance company has not provided sufficient safeguards to protect its own financial viability based on actuarial reasons. These safeguards should take the form of contracts with (prospective) policyholders. Case law has affirmed the duty placed on an insured person to disclose 'material facts', based on Section 59 of the Long-term Insurance Act of 1998. The question is whether the (mis)representation would have materially affected the assessment of risk at the time of issue of the policy, objectively spoken (Joubert v. ABSA Life, 2001).

Many insurance companies do not provide cover if a person tests positive. Insurance companies should adhere to all the principles of HIV testing, i.e. pre-test counselling, informed consent, post-test counselling and confidentiality. This becomes the duty of the medical practitioners involved in testing for insurance purposes. SAMA believes that blanket consent provided for insurance purposes does not conform to the principles of informed consent.

The Promotion of Equality and Prevention of Unfair Discrimination Act of 2000 contains, inter alia, in the illustrative list of unfair. Included is the insurance sector 'unfairly disadvantaging a person or persons, including unfairly and unreasonably refusing to grant services to persons solely on the basis of HIV/AIDS status'. Patients may approach any Magistrate's Court with complaints against insurers if they suspect unfair treatment based on their HIV status.

\section{DEATH NOTIFICATIONS}

The following is an extract from the SAMA HIV Human Rights and Ethics Guidelines.

New regulations on death notifications were passed in 1998. The new death certificate has two pages, which are detachable. It is for authorisation of burial by the Department of Home Affairs. It is used to issue the death certificate. On this page the cause of death can only be indicated as 'natural' or 'unnatural' and no underlying causes are indicated. This is the page the family sees. This page has to be detached from the second. The second page should be placed in a sealed envelope which is then stapled to the first page before handing it to the undertaker and/or family. Undertakers are empowered by law to handle these documents and bound by the same confidentiality as medical practitioners. The second page is confidential and is used by the state (Department of Home Affairs) to collect data. On this the medical cause of death, which may include reference to HIV status, must be indicated. Insurance companies have no right to demand these two pages or copies thereof. If they need a medical report, irrespective of whether it relates to a natural or an unnatural cause of death, it should be requested from the relevant doctors with the necessary supporting documents of consent.

\section{Important contact numbers:}

- Short-term Insurance Ombudsperson

PO Box 30619

Braamfontein, 2017

Tel.: (011) 726-8900

Fax (011) 726-5501
Long-term Insurance Ombudsperson

PO Box 45007

Claremont, 7735

Tel.: (021) 674-0330

Fax (021) 674-0951 